\title{
A new form of raabeia-type actinosporean (Myxozoa) from the oligochaete Uncinais uncinata
}

\author{
Janet Koprivnikar and Sherwin S. Desser
}

Department of Zoology, University of Toronto, 25 Harbord Street, Toronto, Ontario, M5S 3G5, Canada

Key words: Myxozoa, Actinosporea, raabeia, Oligochaeta, Uncinais uncinata

\begin{abstract}
In a study of the oligochaete fauna and their actinosporean parasites in three lakes in Algonquin Park, Canada, a novel form of raabeia-type actinosporean was observed in a single specimen of Uncinais uncinata (Øersted) (Naididae). This form differs from those previously described in its small size, and by having caudal processes that gradually widen and terminate with a single prominent branch.
\end{abstract}

Actinosporean parasites of oligochaetes have been studied extensively since the two-host myxozoan life cycle was elucidated by Wolf and Markiw (1984). The life cycles of myxosporeans in their oligochaete and polychaete hosts as well as the ultrastructure of actinosporeans have been described in several studies (Ruidisch et al. 1991, El-Matbouli et al. 1992, ElMatbouli and Mandok 1995, Bartholomew et al. 1997, Lom et al. 1997, Xiao and Desser 1998a, b, Molnár et al. 1999, Eszterbauer et al. 2000).

As part of an investigation of environmental factors influencing the prevalence and distribution of myxozoans and their hosts (Koprivnikar et al. 2002), oligochaetes in three contiguous lakes in Algonquin Park, Canada, were examined for actinosporean spores. A single specimen of Uncinais uncinata (Øersted) (Naididae) released a novel form of raabeia, which is described in this report.

\section{MATERIALS AND METHODS}

A total of 991 oligochaetes belonging to 17 species were collected from 228 sites in Lake Sasajewun, Broadwing Lake and Kathlyn Lake from May to August 2000. The worms were kept individually in cell-well plates and checked periodically over 2 weeks for actinosporean spores (Yokoyama et al. 1991). Smears of waterborne spores were air dried, stained with Diff-Quik ${ }^{\circledR}$, observed by phase-contrast microscopy, and photographed using a Zeiss Universal I photomicroscope. Measurements of spores were based on five specimens and are given in micrometres as the mean followed by standard deviation

\section{RESULTS}

A single specimen of Uncinais uncinata released raabeia-type actinosporean spores.

Taxonomic summary. Spores: Composed of a styleless epispore with three equal-sized caudal processes, each of which gradually widens and terminates in one prominent branch (Figs 1, 5); polar capsules pyriform; extruded polar filaments observed (Figs 1, 3, 4), length of discharged polar filaments, $3.2 \pm 0.8$; cylindrical spore body (length $=11.2 \pm 0.8$, width $=4.9$ $\pm 0.4)$ contains $17( \pm 1)$ germ cells (Figs. 2-4); nuclei not visible; length of spore from anterior tip of spore body to tip of caudal process, $34.6 \pm 1.8$.

$\mathrm{T}$ y $\mathrm{p}$ e $\mathrm{h}$ o s t: Uncinais uncinata (Øersted) (Oligochaeta: Naididae).

T y p e 1 o c a 1 i t y : Lake Sasajewun, Algonquin Park, Canada $\left(45^{\circ} 35^{\prime} \mathrm{N}, 78^{\circ} 30^{\prime} \mathrm{W}\right)$.

$\mathrm{P} \mathrm{r} \mathrm{e} \mathrm{v} \mathrm{a} 1$ e $\mathrm{n} \mathrm{c}$ e : 1 of 991 oligochaetes belonging to 17 species $(0.09 \%)$.

T y p e s p e c i m e n : Canadian Museum of Nature, Ottawa, catalogue number CMNPA 2001-0004.

Remarks: Differs from previously described raabeiatype spores in that the caudal processes gradually widen and terminate in a prominent branch.

\section{DISCUSSION}

Eleven forms of the conventional genus Raabeia Janiszewska, 1955 have been described (Janiszewska 1955, 1957, Janiszewska and Krzton 1973, Yokoyama et al. 1995, Xiao and Desser 1998a, Molnár et al. 1999). These are Raabeia gorlicensis Janiszewska, 1957, found in Tubifex tubifex; R. magna Janiszewska, 1957 and $R$. furciligera Janiszewska et Krzton, 1973, both recorded in Limnodrilus hoffmeisteri; a raabeia-type actinospore in Branchiura sowerbyi (Yokoyama et al. 1995); six forms of raabeia found in either T. tubifex or L. hoffmeisteri (Xiao and Desser 1998a); and a raabeia-type spore in T. tubifex described by Molnár et al. (1999). Spores of raabeia with bifurcated tails have been described by Molnár et al. (1999) and by Janiszewska and Krzton (1973), but these forms have caudal processes that branch more than once, sometimes in an irregular pattern. The processes of raabeia-type spores previously described also differ in that they gradually taper before branching, whereas the processes of the form described here widen before branching. 

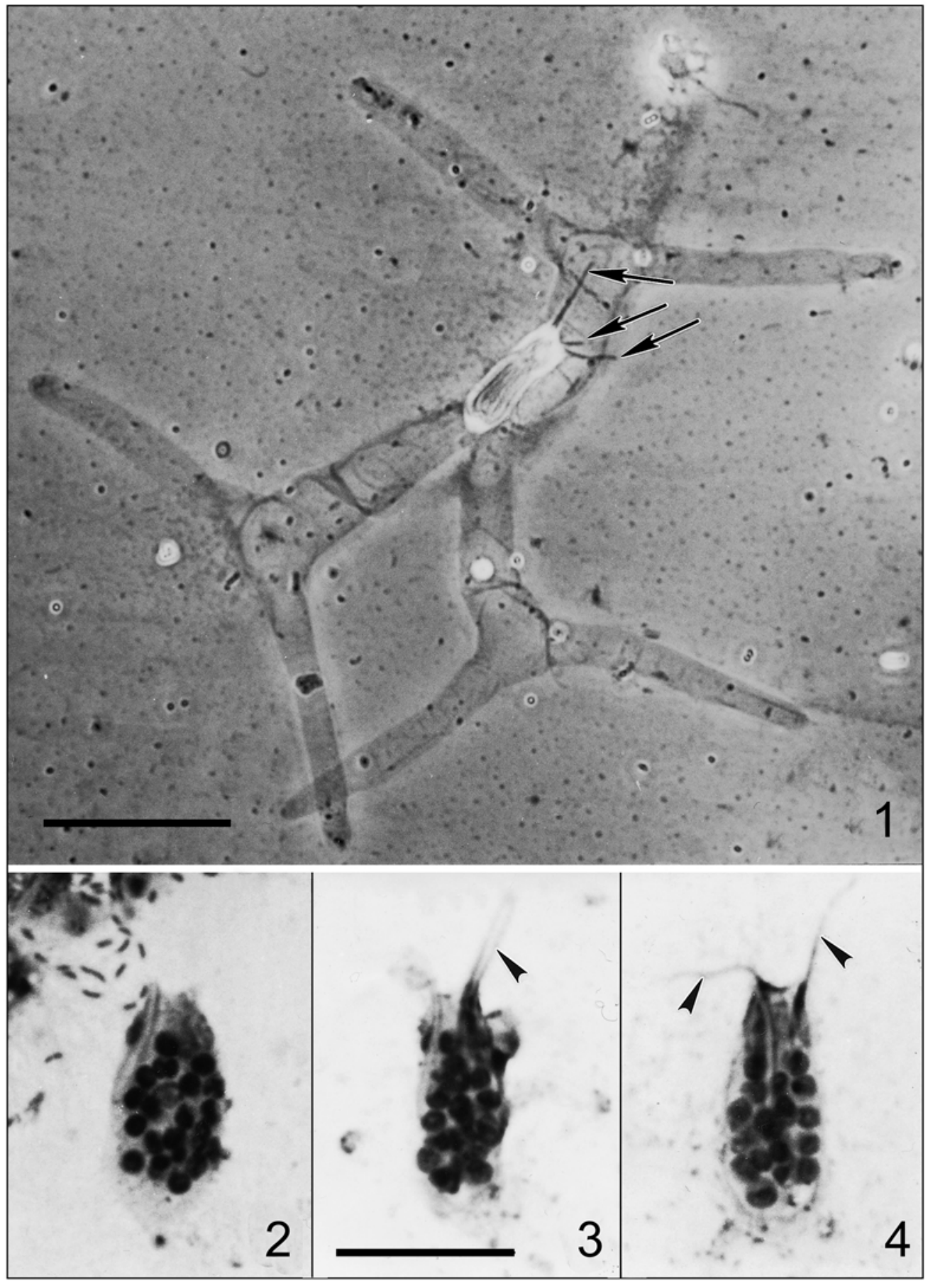

Figs. 1-4. The raabeia-type spore from Uncinais uncinata, phase-contrast micrographs. Fig. 1. Spore with bifurcated caudal processes and discharged polar filaments (arrows). Fig. 2. Spore body with intact polar capsules and 19 germ cells in the sporoplasmic mass. Fig. 3. Spore body with discharged polar filament (arrowhead) and 16 germ cells. Fig. 4. Spore body with 2 discharged polar filaments (arrowheads) and 17 germ cells. Scale bars: Fig. $1=17 \mu \mathrm{m}$; Figs. $2-4=8 \mu \mathrm{m}$.

The overall prevalence of infection in the oligochaetes from the three lakes was $0.09 \%$, corresponding with prevalences observed in previous studies in these lakes (Xiao and Desser 1998a). The natural prevalence, however, is likely higher as not all worms may have released spores during the observation period and recent evidence indicates that large numbers of spores may be contained in the faecal packets of oligochaetes (Gilbert and Granath 2001), thereby decreasing the chance that waterborne spores would be observed. 


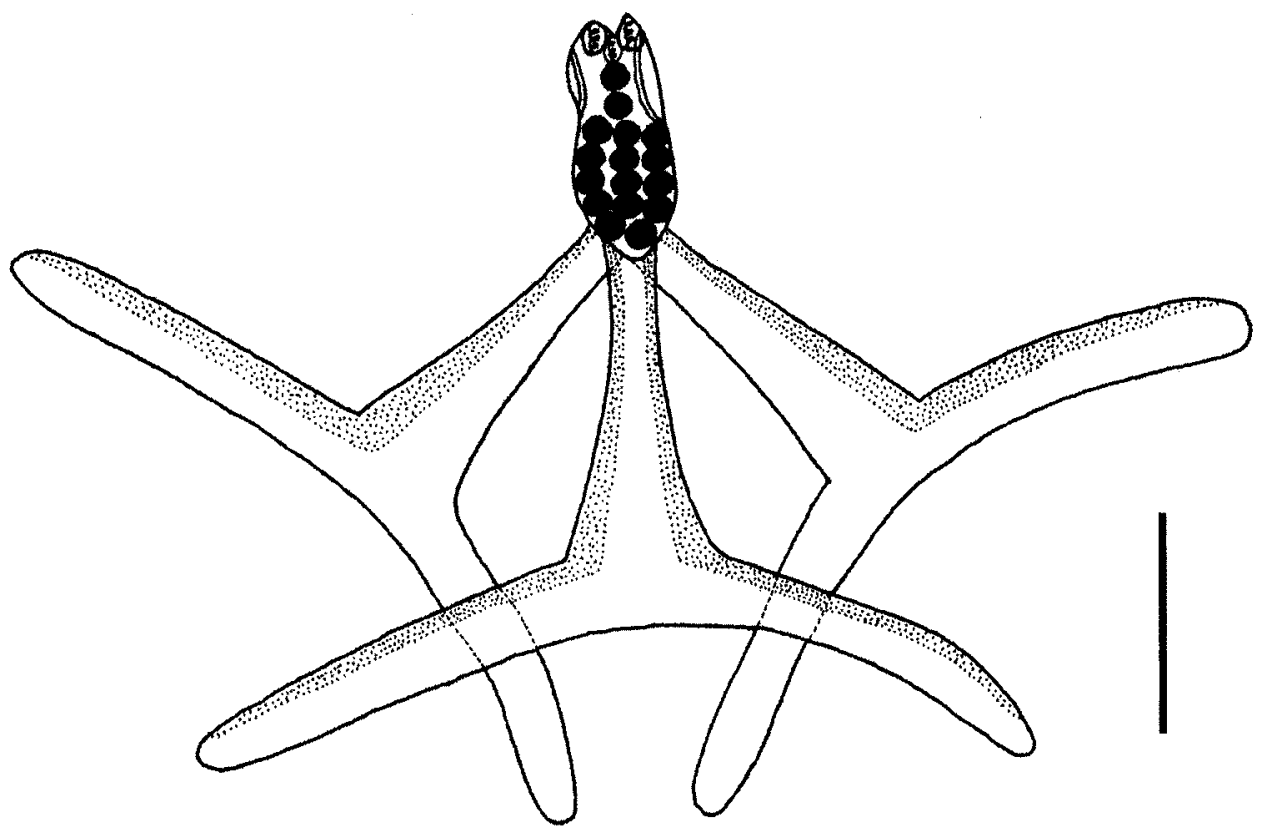

Fig. 5. The raabeia-type spore from Uncinais uncinata, line drawing. Scale bar $=10 \mu \mathrm{m}$.

While the alternate stage for the form of raabeia in this study is unknown, it is most likely a species of Myxobolus, as this association has been described by Lom et al. (1997), and demonstrated by Molnár et al. (1999). Although more than 40 species of Myxobolus have been described from cyprinids in the three lakes in Algonquin Park (Gowen 1983, Li and Desser 1985, Xiao and Desser 1997, Salim and Desser 2000), only 7 forms of raabeia have been observed so far (Xiao and
Desser 1998a), thus providing considerable scope for further research.

Acknowledgements. We thank the Ontario Ministry of Natural Resources for the use of the Wildlife Research Station in Algonquin Park, Dr. Chongxie Xiao, Amanda Martyn, Henry Hong, Donald Stacey, and the WRS staff. This project was supported by the Natural Science and Engineering Research Council of Canada.

\section{REFERENCES}

BARTHOLOMEW J.L., WHIPPLE M.J., STEVENS D.G., FRYER J.L. 1997: The life cycle of Ceratomyxa shasta, a myxosporean parasite of salmonids, requires a freshwater polychaete as an alternate host. J. Parasitol. 83: 859-868.

EL-MATBOULI M., FISCHER-SCHERL T.H., HOFFMANN R.W. 1992: Transmission of Hoferellus carassii Achmerov, 1960 to goldfish Carassius auratus via an aquatic oligochaete. Bull. Eur. Assoc. Fish Pathol. 12: 5456.

EL-MATBOULI M., HOFFMANN R.W., MANDOK C. 1995: Light and electron microscopic observations on the route of the triactinomyxon-sporoplasm of Myxobolus cerebralis from epidermis into rainbow trout cartilage. J. Fish Biol. 46: 919-935.

ESZTERBAUER E., SZÉKELY C., MOLNÁR K., BASKA F. 2000: Development of Myxobolus bramae (Myxosporea: Myxobolidae) in an oligochaete alternate host, Tubifex tubifex. J. Fish Dis. 23: 19-25.

GILBERT M.O., GRANATH W.O. 2001: Persistent infection of Myxobolus cerebralis, the causative agent of salmonid
Whirling Disease, in Tubifex tubifex. J. Parasitol. 87: 101107.

GOWEN D.E. 1983: The myxosporean parasites of six species of fish (Cyprinidae) from Lake Sasajewun, Algonquin Park, Canada. M.Sc. thesis. University of Toronto, Toronto, $424 \mathrm{pp}$.

JANISZEWSKA J. 1955: Actinomyxidia. Morphology, ecology, history of investigations, systematics, development. Acta Parasitol. Pol. 2: 405-433.

JANISZEWSKA J. 1957: Actinomyxidia II. New systematics, sexual cycles, description of new genera and species. Zool. Pol. 8: 3-34.

JANISZEWSKA J., KRZTON M. 1973: Raabeia furciligera sp. n. (Cnidosporidia: Actinomyxidia) from the body cavity of Limnodrilus hoffmeisteri Claparede, 1862. Acta Protozool. 12: 165-167.

KOPRIVNIKAR J., KOEHLER A., RODD F.H., DESSER S.S. 2002: Environmental factors affecting the prevalence and distribution of myxozoan parasites and their hosts in three lakes in Algonquin Park, Ontario. J. Parasitol. 87: In Press. 
LI L., DESSER S.S. 1985: The protozoan parasites of fish from two lakes in Algonquin Park, Ontario. Can. J. Zool. 63: $1846-1858$

LOM J., McGEORGE J., FEIST S.W., MORRIS D., ADAMS A. 1997: Guidelines for the uniform characterisation of the actinosporean stages of parasites of the phylum Myxozoa. Dis. Aquat. Org. 30: 1-9.

MOLNÁR K., EL-MANSY A., SZÉKELY C., BASKA F. 1999: Development of Myxobolus dispar (Myxosporea: Myxobolidae) in an oligochaete alternate host, Tubifex tubifex. Folia Parasitol. 46: 15-21.

RUIDISCH S., EL-MATBOULI M., HOFFMANN R.W. 1991: The role of tubificid worms as an intermediate host in the life cycle of Myxobolus pavlovskii (Akhmerov, 1954). Parasitol. Res. 77: 663-667.

SALIM K.Y., DESSER S.S. 2000: Descriptions and phylogenetic systematics of Myxobolus spp. from cyprinids in Algonquin Park, Ontario. J. Euk. Microbiol. 47: 309-318.

WOLF K., MARKIW M.E. 1984: Biology contravenes taxonomy in the Myxozoa: new discoveries show alternation of invertebrate and vertebrate hosts. Science 225: 1449-1452.

XIAO C., DESSER S.S. 1997: Sphaerospora ovophila n. sp. and Myxobolus algonquinensis n. sp. (Myxozoa: Myxo- sporea), ovarian parasites of fish from Algonquin Park, Ontario, Canada. J. Euk. Microbiol. 44: 157-161.

XIAO C., DESSER S.S. 1998a: Actinosporean stages of myxozoan parasites of oligochaetes from Lake Sasajewun, Algonquin Park, Ontario: new forms of triactinomyxon and raabeia. J. Parasitol. 84: 998-1009.

XIAO C., DESSER S.S. 1998b: Actinosporean stages of myxozoan parasites of oligochaetes from Lake Sasajewun, Algonquin Park, Ontario: new forms of echinoactinomyxon, neoactinomyxon, aurantiactinomyxon, guyenotia, synactinomyxon and antonactinomyxon. J. Parasitol. 84: 1010-1019.

YOKOYAMA H., OGAWA K., WAKABAYASHI H. 1991: A new collection method of actinosporeans - A probable infective stage of myxosporeans to fishes from tubificids and experimental infection of goldfish with the actinosporean, Raabeia sp. Fish Pathol. 26: 133-138.

YOKOYAMA H., OGAWA K., WAKABAYASHI H. 1995: Myxobolus cultus n. sp. (Myxosporea: Myxobolidae) in the goldfish Carassius auratus transformed from the actinosporean stage in the oligochaete Branchiura sowerbyi. J. Parasitol. 81: 446-451. 